\title{
Implementasi Learning Manegement System (LMS) Berbantukan Edmodo untuk Meningkatkan Hasil Belajar Siswa pada Materi Fluida Dinamis
}

\author{
Julius Zai ${ }^{*}$, Suji Ardianti ${ }^{2}$, Franciska Ayuningsih Ratnawati ${ }^{3}$, Suci Nujul Hayati ${ }^{4}$ \\ ${ }^{124}$ Program Studi Pendidikan Fisika, Fakultas Keguruan dan Ilmu Pendidikan, Universitas Ahmad Dahlan Yogyakarta \\ ${ }^{3}$ SMA Negeri I Gamping, Yogyakarta \\ ${ }^{124}$ Kampus 2, Jl. Pramuka 42, Sidikan Umbulharjo Yogyakarta, Yogyakarta 5516, Indonesia \\ ${ }^{3}$ Tegalyoso-Banyuraden- Gamping-Sleman Yogyakarta, Yogyakarta 5529, Indonesia \\ *Email: Juliusjay927@gmail.com
}

\section{Article Info: Submitted: 2/03/2020 | Revised: 17/03/2020 | Accepted: 20/03/2020}

Intisari - Pada abad 21, menekankan sistem pembelajaran pembaharuan menggunakan teknologi informasi dan komunikasi (TIK). Salah satu menggunakan learning management system (LMS). Penelitian ini bertujuan untuk mengetahui adanya efektivitas dalam implementasi pembelajaran Learning Management System (LMS) berbantukan Edmodo untuk meningkatkan hasil belajar peserta didik pada materi fluida dinamis. Penelitian ini dilakukan di salah satu SMA Negeri 1 Gamping dengan desain penelitian quasi eksperimen. Sebagai Sampel dalam penelitian ini adalah kelas X sebanyak 11 siswa, yang dipilih dengan random sampling. Instrumen pengambilan data penelitian ini menggunakan pretes dan posttest dan hasil penelitian diuji dengan analisis N-Gain. Hasil penelitian menunjukkan bahwa hasil belajar peserta didiik meningkat pada kategori tinggi dengan respon siswa sangat baik. Hal ini berarti, Learning Management System (LMS) berbantukan Edmodo sangat efektif untuk meningkatkatkan hasil belajar peserta didik pada materi fluida dinamis.

Kata kunci: Edmodo, Learning Management System (LMS), Fluida dinamis, Hasil belajar

Abstract - In the 21st century, emphasizing renewal learning systems using information and communication technology (ICT). One uses a learning management system (LMS). This study aims to determine the effectiveness in implementing the learning Management System (LMS) aided by Edmodo to improve student learning outcomes on dynamic fluid material. This research was conducted at one of the Gamping 1 High Schools with a quasi-experimental research design. As a sample in this study were 11th grade $X$ students, selected by random sampling. The research data collection instrument used to pretest and posttest and the results of the study were tested by N-Gain analysis. The results showed that the learning outcomes of students increased in the high category with very good student responses. This means Edmodo-assisted Learning Management System (LMS) is very effective to improve student learning outcomes on dynamic fluid material.

Keywords: Edmodo, Learning Management System (LMS), Dynamic fluid, Learning

\section{PENDAHULUAN}

Seiring dengan berjalannya waktu inovasi-inovasi terus diciptakan oleh para ilmuan maupun peneliti terutama titik fokusnya untuk menjembatani dalam hal kelangsungan hidup manusia. Hal tersebut merupakan tonggak dasar dalam hal proses kehidupan agar tercipta sumber daya manusia yang berkualitas. Salah satu inovasi yang sangat pesat yakni perkembangan teknologi dan informasi terutama dalam bidang pendidikan.

Sistem pendidikan pada saat ini, berfokus pada pembelajaran abad ke 21. Pembelajaran abad ke 21 merupakan sistem gerakan-gerakan pembaharuan pendidikan terutama dalam bidang sains dan matematika. Pada abad 21, menekankan sistem pembelajaran pembaharuan menggunakan teknologi, informasi dan komunikasi (TIK).

Proses pembelajaran menggunakan media internet berbeda dari proses pembelajaran tatap muka dengan guru, jadi penggunaan media internet membutuhkan pertimbangan berupa resiko, sistem, struktur, jadwal dan biaya. Salah satu solusi yang dapat dilakukan adalah menggunakan learning management system (LMS). LMS memiliki ruang lingkup pengiriman materi, penilaian, pemantauan dan komunikasi [1]. LMS mengintegrasikan konten 
material, pedagogis, dan kompetensi profesional, sains dan teknologi dengan harap dapat meningkatkan hasil pembelajaran yang optimal. Fleksibilitas LMS sangat memungkinkan pendidik dan peserta didik mengaksesnya kapan saja dan dimana saja serta melalui device apa saja (PC, tablet, ataupun smartphone). Learning Management System banyak sekali [2].

Untuk mendukung penggunaan LMS, salah satunya bisa menggunakan edmodo. Edmodo adalah media komunikasi dan diskusi antara guru dan siswa secara efisien, dan dengan disainnya hampir menyerupai facebook [1], juga menambahkan bahwa learning management system (LMS) suatu aplikasi yang dapat menciptakan suatu model dalam memecahkan suatu masalah [3].

Menggunakan edmodo dari tingkat kegunaan, kemudahan penggunaan, kemudahan belajar dan kepuasaan ternyata edmodo pada tingkat kedua ditinjau dari respon dari sistem pembelajaran dan merupakan aplikasi yang cenderung dipersepsi paling baik oleh siswa [4]. Serta aplikasi pembelajaran berbasis proyek yang dibantu oleh platform edmodo menciptakan dampak positif pada keterampilan dan prestasi akademik calon guru yang puas setelah melakukan kegiatan di platform edmodo [5] .

Dari hal tersebut maka aplikasi ini perlu dimanfaatkan dalam pembelajaran dengan berbagai sistem pembelajaran yang digunakan. Dengan melakukan penelitian untuk melihat respon siswa setelah belajar menggunakan learning management system berupa aplikasi edmodo, serta melihat sejauh mana efektivitas implementasinya dalam meningkatkan hasil belajar siswa pada materi fluida dinamis.

\section{LANDASAN TEORI}

\subsection{Learning Management System (LMS)}

Learning Management System (LMS) merupakan teknologi yang berkembang dalam masyarakat saat ini, yang menyediakan pelatihan pembuatan, pengiriman, manajemen, pelacakan, pelaporan, dan penilaian materi pembelajaran online [6]. LMS sangat berguna dalam menciptakan lingkungan/suasana belajar yang lengkap bagi peserta didik, karena penuh dengan penyediaan dokumen yang terkait modul dalam format elektronik, kesempatan untuk saling belajar bersama-sama sangat terbuka. Penggunaan teknologi yang munculdalam pendidikan dapat mengatasi tantangan yang dihadapi pendidikan tinggi di sub-Sahara Afrika [7].

Selain itu, learning management system memiliki komponen teknologi infrastruktur yang merupakan konten e-Learning, pengguna e-Learning [8]. Setiap peserta didik memiliki akses ke semua konten pembelajaran yang lebih fleksibilitas waktu dan cocok untuk kebutuhan peserta didik dalam belajar secara mandiri sesuai kemampuan kecepatan belajar masingmasing, dan berpartisipasi dalam kesempatan belajar yang interaktif.

Disisi lain, learning management systemmemiliki tiga tipe pengguna yakni guru, peserta didik dan administrator. Penggunaan LMS dapat membatu terbentuknya pengembangan konsep dan karakter peserta didik. Menggunakan LMS pada pembelajaran fisika efektif meningkatkan penguasaan konsep serta pengembangan karakter peserta didik [9].

\subsection{Media Edmodo}

Edmodo adalah pembelajaran berbasis jejaring sosial yang aman dan gratis dalam memudahkan guru untuk membuat dan mengelola kelas virtual sehingga peserta didik dapat terhubung dengan teman sekelas dan guru kapan saja dan dimana saja [10]. Edmodo terus dikembangkan oleh Nicolas Borg and Jeff O'Hara sebagai platform pembelajaran untuk berkolaborasi dan terhubung antara siswa dan guru dalam berbagi konten pendidikan, mengelola proyek atau tugas dan menangani pemberitahuan setiap aktivitas.

Edmodo dirancang untuk membuat peserta didik semakin bersemangat belajar di lingkungan yang lebih akrab. Di dalam Edmodo, guru dapat melanjutkan diskusi kelas online dengan memberikan polling untuk memeriksa pemahaman peserta didik, dan lencana penghargaan kepada peserta didik secara individual berdasarkan kinerja atau perilaku. Dalam pembelajaran Edmodo, guru berada di tengah-tengah jaringan yang kuat yang menghubungkan guru kepada peserta didik, administrator, dan orang tua. Jaringan ini salah satu sumber daya terbaik di dunia yang bisa dijadikan sebagai alat media, karena menyediakan fitur-fitur yang dapat digunakan di dunia pendidikan yang berkualitas tinggi.

Selain itu, edmodo menggunakan desain yang mirip dengan Facebook, hal ini sejalan dengan Sudibjo menyatakan bahwa edmodo diciptakan menggunakan konsep yang mirip dengan facebook, dimana tujuan pembuatannya adalah khusus untuk bidang 
pendidikan yang dapat mendukung pembelajaran secara online [11]. Bahkan banyak yang mengatakan edmodo suatu situs facebook-nya sekolah, karena selain media jejaring sosial juga dapat digunakan dalam mendukung proses pembelajaran yang menghubungkan guru dengan peserta didik secara berkolaborasi jarak jauh.

Aplikasi Edmodo ini juga dilengkapi dengan beberapa aktivitas pembelajaran, seperti Quiz, Assignment dan Poll. Untuk bahan ajar, Edmodo mendukung bahan ajar berupa File dan Link. Guru juga dapat mengirim nilai, tugas dan kuis kepada siswa. Siswa dapat mengerjakan pekerjaan rumah dan melihat nilai-nilai mereka dan komentar guru yang telah diposting tentang tugas mereka. Guru juga dapat membuat bahan dan topik posting untuk diskusi dikalangan peserta didik, serta guru dapat membedakan dan menciptakan belajar mandiri melalui penciptaan sub-kelompok dalam kursus. Setelah setiap periode kursus selesai, guru menutup keluar jaringan dan menciptakan yang baru untuk kursus berikutnya.

\subsection{Hasil Belajar}

Hasil belajar sering dijadikan tolak ukur untuk mengetahui seberapa jauh kemampuan peserta didik menguasi materi yang sudah diajarkan. Hasil belajar terjadi dari proses belajar mengajar dan motivasi serta harapan yang timbul dari diri sendiri untuk berhasil serta masukan dari lingkungan berupa rancangan dan pengelolaan motivasional tidak berpengaruh terhadap besar kecilnya usaha yang dicurahkan oleh siswa untuk mencapai tujuan belajar.

Selain itu, hasil belajar memberi perubahan pada tingkah laku baik dalam pengetahuan, pemahaman, sikap, dan keterampilan peserta didik sehinga menjadi lebih baik dari sebelumnya. Perubahan perilaku disebabkan karena tingkat penguasaan materi yang dicapai oleh peserta didikdalam kegiatan proses belajar mengajar. Hasil belajar adalah pola perbuatan, nilai-nilai, pengertian, sikap, apresiasi dan keterampilan. Hal ini dapat berupa aspek kognitif, aspek afektif, dan aspek psikomotor[8] [12].

Hasil belajar salah satu indikator dari proses belajar. Dalam meningkatkan hasil belajar peserta didik, guru perlu menerapakan metode pembelajaran yang dapat mendorong keterlibatan peserta didik dalam pembelajaran [13]. Salah satu indikator tercapai atau tidaknya suatu proses pembelajaran adalah dengan melihat hasil belajar yang dicapai oleh peserta didik.

\subsection{Fluida Dinamis}

Fluida dinamis adalah fluida (bisa berupa zat cair, gas) yang bergerak. Untuk memudahkan dalam mempelajari, fluida disini dianggap steady (mempunyai kecepatan yang konstan terhadap waktu), tak termampatkan (tidak mengalami perubahan volume), tidak kental, tidak turbulen (tidak mengalami putaran-putaran).

a. Persamaan Kontinuitas

Air yang mengalir di dalam pipa air dianggap mempunyai debit yang sama di sembarangtitik. Atau jika ditinjau 2 tempat, maka: Debit aliran 1 = Debit aliran 2. Misalnya, kecepatan fluida didalam penampang $A_{1}$ sebesar $V_{1}$ dan dalam penampang $A_{2}$ sebesar $V_{2}$ seperti pada Persamaan 1 dan Gambar 1.

$A_{1} v_{1}=A_{2} v_{2}$

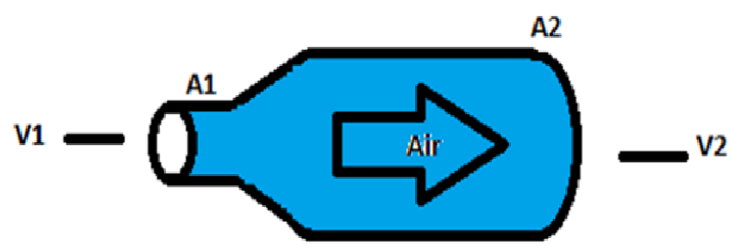

Gambar 1. Arus fluida

\section{b. Hukum Bernoulli}

Persamaan yang telah dihasilkan oleh Bernoulli tersebut juga dapat disebut sebagai Hukum Bernoulli, yakni suatu hukum yang dapat digunakan untuk menjelaskan gejala yang berhubungan dengan gerakan zat alir melalui suatu penampang pipa [14]. Hukum Bernoulli dapat di contohkan pada sebuah pipa, jika terdapat aliran fluida pada suatu pipa yang luas penampang dan ketinggiannya tidak sama. Misalnya, massa jenis fluida $\mathrm{Q}$, kecepatan fluida pada penampang $A_{1}$ sebesar $V_{1}$, dalam waktu $t$ panjang bagian system yang bergerak ke kanan $V_{1}$.t. Pada penampang $A_{2}$ kecepatan $V_{2}$ dan dalam waktu $\mathrm{t}$ system yang bergerak ke kanan $V_{2} . t$.

Pada penampang $A_{1}$ fluida mendapat tekanan $\mathrm{p}_{1}$ dari fluida di kirinya dan pada penampang $A_{2}$ mendapat tekanan: dari fluida di kananya. Gaya pada 
$A_{1}$ adalah $F_{1}=P_{1}$. Sedangkan $A_{1}$ dan penampang $A_{1}$ adalah $F_{2}=P_{2}$ dan $A_{2}$. Dan dapat dirumuskan :

$P+\frac{1}{2} \rho v_{1}^{2}+\rho g h=$ konstan

Rumus di atas dinamakan persamaan Bernouli untuk aliran fluida yang tidak kompresibel. Persamaan tersebut pertama kali diajukan oleh Daniel Bernouli dalam teorinya Hidrodinamika [15].

\section{METODE PENELITIAN}

Penelitian ini menggunakan metode quasi eksperimental dengan pemilihan sampel menggunakan cara random sampling. Sampel dalam penelitian ini adalah peserta didik kelas X SMAN 1 Gamping, Sleman, Yogyakarta sebanyak 11 peserta didik dari dua kelas sebanyak 64 orang. Penelitian ini menggunakan proses pembelajaran berbasis learning management system menggunakan aplikasi Edmodo pada materi fluida dinamis. Desain penelitian berbentuk Pre-test Post-test One Group Design. Desain penelitian dapat dilihat pada Tabel 1 .

Tabel 1. Desain penelitian satu kelompok pre-test dan post-test

\begin{tabular}{ccc}
\hline Pretest & Treatment & Posttest \\
\hline $\mathrm{Q}_{1}$ & $\mathrm{X}$ & $\mathrm{Q}_{2}$ \\
\hline
\end{tabular}

Prosedur penelitian ini terdiri dari tiga tahapan yaitu tahap persiapan, tahap pelaksanaan dan tahap akhir. Langkah-langkah pada setiap tahap dalam setiap prosedur penelitian ini lebih jelasnya sebagai berikut.

\subsection{Tahap Persiapan}

Pada tahap persiapan, hal yang dilakukan yakni menentukan judul penelitian, melakukan studi pustaka yang berkaitan dengan judul yang telah ditentukan, melakukan observasi, menentukan sampel penelitian menggunakan teknik purpose sampling, membuat proposal penelitian, serta menyusun instrumen penelitian berupa silabus, rencana pelaksanaan pembelajaran (RPP) dan soal essay pretest dan posstest untuk siswa.

\subsection{Tahap Pelaksanaan}

Pada pembelajaran ini, adapun tahapan yang diinstruksikan pada fitur: quiz memberikan pretest pada siswa yang berisi soal essay yang terdiri dari lima soal; di assigment mengupload materi tentang fluida dinamis; pada note mengupload LKS untuk dikerjakan oleh peserta didik; melalui fitur quiz memberikan posttest untuk mengevaluasi kembali pembelajaran yang telah dilaksanakan; melalui quiz juga memberikan soal remedial bila ada siswa yang belum mencapai standar kelulusan; dan pada fitur poll akan dilakukan penilaian aplikasi Edmodo oleh siswa.

\subsection{Tahap Akhir}

Pada tahap akhir menganalisis data hasil terakhir (posttest) dan menyimpulkan dan menyusun laporan akhir penelitian. Instrumen yang digunakan dalam penelitian ini berupa silabus, rencana pelaksanaan pembelajaran (RPP), lembar kegiatan peserta didik (LKS), pretest dan posttest. Instrumen telah divalidasi oleh ahli dengan hasil validasi bahwa instrument yang digunakan valid. Untuk mengukur penguasaan peserta didik terhadap materi yang diajarkan oleh guru atau dipelajari oleh peserta didik menggunakan pretest dan posttest. Adapun tes yang digunakan yaitu tes objektif berupa soal pilihan berganda. Tingkat penguasaan Hasil Belajar Siswa (HBS) menggunakan interval pada Tabel 2.

Tabel 2. Tingkat Penguasaan Hasil Belajar

\begin{tabular}{cc}
\hline Interval & Kategori Hasil Belajar \\
\hline $0 \leq H B S<40$ & Sangat Rendah \\
$40 \leq H B S<60$ & Rendah \\
$60 \leq H B S<75$ & Sedang \\
$75 \leq H B S<90$ & Tinggi \\
$90 \leq H B S<100$ & Sangat Tinggi \\
\hline
\end{tabular}

Ketuntasan hasil belajar dapat dihitung dengan menggunakan Persamaan 3.

$K B=T / t \times 100 \%$

Keterangan :

$K B=$ ketuntasan Belajar

$T \quad=$ jumlah siswa yang tuntas

Pengolahan data dalam penelitian ini dimulai dengan menghitung nilai pretest dan posttest. Selanjutnya, efektivitas implementasi pembelajaran LMS berbantukan Edomodo untuk meningkatkan hasil belajar siswa ditentukan dengan menggunakan analisis keuntungan yang dinormalisasi. Efektivitas implementasi pembelajaran LMS berbantukan edomodo pada materi fluida dihitung dengan 
menggunakan Persamaan 4 gain normal $<$ g $>$ sebagai berikut:

Gain Normal $(g)=\frac{(\text { Nilai Pretest }- \text { Nilai Posttest })}{(\text { Nilai Max }- \text { Nilai Pretest })}$

Dengan kriteria gain dinormalisasi [16], dapat dilihat pada Tabel 3.

Tabel 3. Kriteria gain normalisasi

\begin{tabular}{ll}
\hline \multicolumn{1}{c}{ Gain Normal $(g)$} & \multicolumn{1}{c}{ Kriteria } \\
\hline$(<g>) \geq 0.7$ & Tinggi \\
$0,3<(<g>)<0.7$ & Sedang \\
$(<g>)<0.3$ & Rendah \\
\hline
\end{tabular}

\section{HASIL DAN PEMBAHASAN}

Dari data hasil nilai pretest dan posttest yang telah diperoleh setelah dianalisis mengguanakan kritereia tingkat penguasaan hasil belajar dengan berbantukan media edmodo menunjukan adanya peningkatan dari interval pretest $50 \%$ pada kategori rendah menjadi interval posttest $80 \%$ kategori tinggi. Penguasaan hasil belajar dapat dilihat pada Gambar 2. Peningkatan dari hasil sebelum penerapan edmodo dengan sesudah penerapan edmodo mengalami kenaikan sebesar $60 \%$ dari hasil semula, hal ini memperlihatkan kenaikan secara signifikan. Siswa menunjukkan respon yang positif dan bagus dalam pembelajaran, pembelajaran edmodo sebagai e-learning yang diterapkan dalam pembelajaran membawa suasana pembelajaran lebih berbeda dan lebih menyenangkan.

Hasil pretes dan postes setiap peserta didik pada materi fluida dinamis untuk melihat peningkatan hasil belajar siswa pembelajaran berbantukan edmodo dapat dilihat pada Gambar 3. Gambar 3 menunjukkan peningkatan hasil belajar peserta didik terlihat efektifitas implementasi pembelajaran berbantuan
Edmodo. Dari 11 siswa ada dua siswa yang mendapatkan nilai posttes 100 dari sebelumnya yang mendapatkan nilai pretest 70 . Matri fluida dinais merupakan materi yang cukup sulit dan abstrak, terutama pemahaman tentang persamaan kontinuitas dan hukum Bernaulli. Materi ini memerlukan simulasi atau untuk memperjelas pemahaman siswa, dengan edmodo simulasi materi terutama hukum Bernaulli dapat diterapkan dalam bentuk video yang disipkan dalam edmodo. Siswa dapat mempelajari materi tersebut secara berulang-ulang ketika belum paham aatau memang memerlukan penjelasan lebih.

Grafik menunjukan data bahwa tiap peserta didik mengalami peningkatan hasil belajar yang berarti ada peningkatan penguasan konsep secara keseluruhan pada materi fluida dinamis. Hal ini sejalan dengan Rahmadika Sudibyo, bahwa penggunaan Edmodo efektif dalam meningkatkan hasil belajar peserta didik [8]. Hasil rata-rata nilai pretest, posttest, gain, dan N-gain dapat dilihat pada tabel 3.

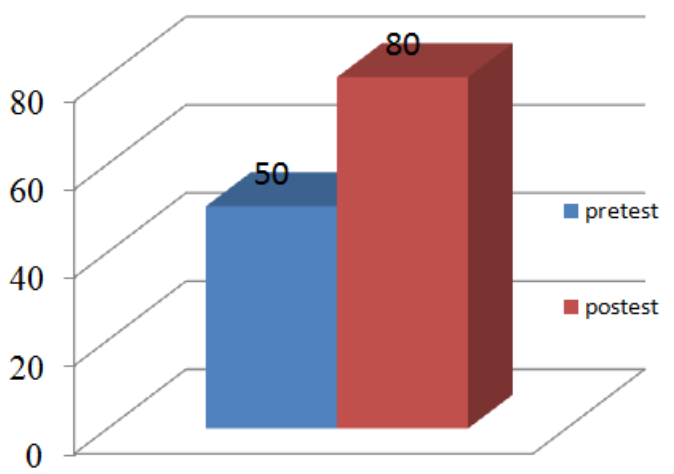

Gambar 2. Grafik Penguasaan hasil belajar

Berdasarkan Tabel 3, jika diperhatikan terlihat hasil efektifitas implementasi pembelajaran berbantuan Edmodo dengan nilai N-gain sebesar 1,5 pada kategori tinggi.

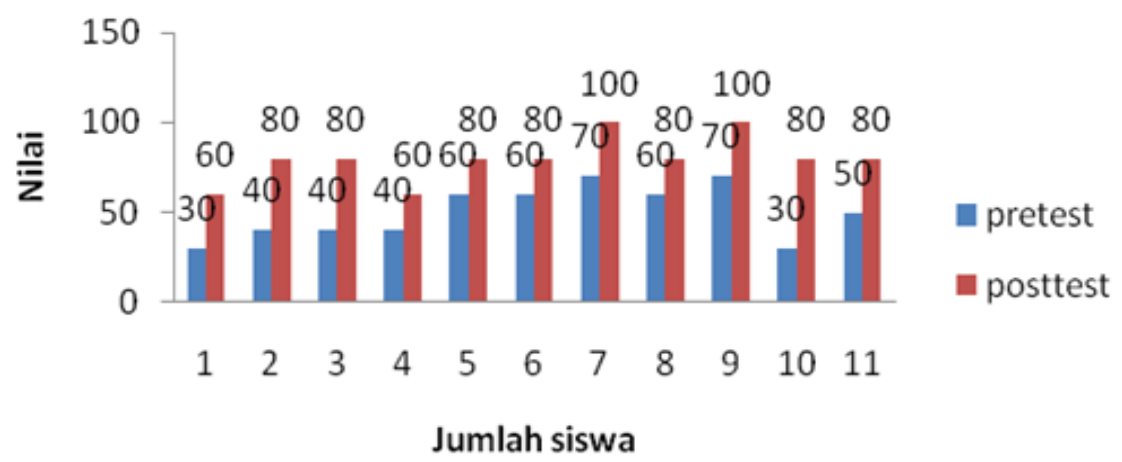

Gambar 3. Grafik peningkatan hasil belajar peserta didik pembelajaran berbantukan Edmodo 
Pada pembelajaran learning management system berbantukan Edomodo peserta didik mengalami pengalaman langsung berinteraksi antara guru dan teman sesama di dalam group pembelajaran. Peserta didik berantusias memberi respon atau tanggapan pada kolom komentar dan dengan memberi tanda emotion dan komentar.

Tabel 3. Rata-rata Nilai Pretest, Postest, Gain dan Ngain

\begin{tabular}{ccccccc}
\hline $\begin{array}{c}\text { Sumber } \\
\text { data }\end{array}$ & \multicolumn{5}{c}{ Rata-rata } \\
\hline Soal & $\mathrm{N}$ & $\begin{array}{c}\text { Pre- } \\
\text { test }\end{array}$ & $\begin{array}{c}\text { Post- } \\
\text { test }\end{array}$ & Gain & $\begin{array}{c}\text { N- } \\
\text { gain }\end{array}$ & Kategori \\
\hline & 10 & 50 & 80 & 30 & 1.5 & Tinggi \\
\hline
\end{tabular}

Hal ini sesuai dengan hasil Sudibyo, bahwa pembelajaran berbantuan Edmodo dapat meningkatkan respon peserta didik [8]. Peserta didik saling berinteraksi, mendiskusikan materi pembelajaran yang telah dipelejari dan yang akan dipelajari. Siswa akan lebih tertarik dantertantang dengan adanya pembelajaran berbantuan edmodo dengan tampilan yang menarik, sehingga siswa lebih mudah memahami materi yang diberikan [16].

\section{KESIMPULAN}

Berdasarkan hasil penelitian yang telah dilakukan, dapat ditarik suatu kesimpulkan bahwa pembelajaran learning management system berbantukan Edmodo pada materi fluida dinamis efektif unutk meningkatkan hasil belajar peserta didik dengan respon yang sangat baik.

\section{DAFTAR PUSTAKA}

[1] G. Septia Wulandari, "The Development of Learning Management System Using Edmodo," MSEE, vol. 336, no. 1, p. 012046, 2018.

[2] S. Ardianti, D. Sulisworo, and Y. Pramudya, "Efektivitas Blended Learning berbasis Pendekatan STEM Education Berbantuan Schoology untuk Meningkatkan Critical Thinking Skill pada Materi Fluida Dinamik," 2019, vol. 2.

[3] D. Sulisworo and K. Permprayoon, "What is the Better Social Media for Mathematics Learning? A Case Study at A Rural School in Yogyakarta, Indonesia," Int. J. Emerg. Math. Educ., vol. 2, no. 1, pp. 39-48, 2018.
[4] C. Hursen, "The impact of edmodo-assisted project-based learning applications on the inquiry skills and the academic achievement of prospective teachers," TEM J., vol. 7, no. 2, pp. 446-455, 2018.

[5] K. Mershad and P. Wakim, "A learning management system enhanced with internet of things applications.," J. Educ. Learn., vol. 7, no. 3, pp. 23-40, 2018.

[6] J. Mtebe, "Learning management system success: Increasing learning management system usage in higher education in sub-Saharan Africa," Int. J. Educ. Dev. Using ICT, vol. 11, no. 2, 2015.

[7] N. Harrati, I. Bouchrika, and Z. Mahfouf, "eLearning: On the uptake of modern technologies for online education," 2016, pp. 162-166.

[8] A. T. Wibowo, I. Akhlis, and S. E. Nugroho, "Pengembangan LMS (Learning Management System) Berbasis Web untuk Mengukur Pemahaman Konsep dan Karakter Siswa," Sci. J. Inform., vol. 1, no. 2, pp. 127-137, 2014.

[9] K. Balasubramanian, V. Jaykumar, and L. N. Fukey, "A study on 'Student preference towards the use of Edmodo as a learning platform to create responsible learning environment,'"' Procedia-Soc. Behav. Sci., vol. 144, no. 1, pp. 416422, 2014.

[10] A. Sudibyo, "Penggunaan Media Pembelajaran Fisika dengan E-Learning Berbasis Edmodo Blog Education pada Materi Alat Optik untuk Meningkatkan Respons Motivasi dan Hasil Belajar Siswa di SMP Negeri 4 Surabaya," Inov. Pendidik. Fis., vol. 2, no. 3, 2013.

[11] A. Suprijono, Cooperative learning: teori $\mathcal{E}$ aplikasi PAIKEM. Pustaka Pelajar, 2009.

[12] L. Widayanti, "Peningkatan aktivitas belajar dan hasil belajar siswa dengan metode problem based learning pada siswa kelas VIIA MTS Negeri Donomulyo Kulon Progo tahun pelajaran 2012/2013," J. Fis. Indones., vol. 17, no. 49, 2013.

[13] K. Abidin and S. Wagiani, "Studi analisis perbandingan kecepatan aliran air melalui pipa venturi dengan perbedaan diameter pipa," Dinamika, vol. 4, no. 1, 2015.

[14] D. C. Giancoli, "Fisika: Prinsip dan Aplikasi Edisi ke 7Jilid 1," Jkt. Erlangga, 2014.

[15] R. R. Hake, "Analyzing change/gain scores," Unpubl. URL Httpwww Phys. Indiana Edu SdiAnalyzingChange-Gain Pdf, 1999. 


\section{RADIASI: Jurnal Berkala Pendidikan Fisika}

Volume 13 Nomor 01, Bulan April, Tahun 2020, pp: 7-13

Available online at: http://jurnal.umpwr.ac.id/index.php/radiasi/index

p-ISSN: 2302-6111 e-ISSN: 2549-0826

[16] S. Rahmadika, "Efektivitas Penerapan Media Jejaring Sosial Edmodo dalam Meningkatkan Hasil Belajar Siswa pada Mata Diklat Sistem Komputer," 2014. 